\title{
Maternal hypothyroxinemia influences glucose transporter expression in fetal brain and placenta
}

\author{
M R Pickard, A K Sinha, L M Ogilvie, A J Leonard, P R Edwards \\ and $\mathbf{R}$ P Ekins
}

Division of Molecular Endocrinology, University College London Medical School, Mortimer Street, London W1N 8AA, UK

(Requests for offprints should be addressed to A K Sinha)

\begin{abstract}
The influence of maternal hypothyroxinemia on the expression of the glucose transporters, GLUT1 and GLUT3, in rat fetal brain and placenta was investigated. Fetal growth was retarded in hypothyroxinemic pregnancies, but only before the onset of fetal thyroid hormone synthesis. Placental weights were normal, but placental total protein concentration was reduced at 19 days gestation (dg). Immunoblotting revealed a decreased abundance of GLUT1 in placental microsomes at $16 \mathrm{dg}$, whereas GLUT3 was increased. Fetal serum glucose levels were reduced at $16 \mathrm{dg}$. In fetal brain, the concentration of microsomal protein was deficient at $16 \mathrm{dg}$ and the abundance of parenchymal forms of GLUT1 was further depressed, whereas GLUT3 was unaffected. Northern hybridization analysis
\end{abstract}

demonstrated normal GLUT1 mRNA levels in placenta and fetal brain.

In conclusion, maternal hypothyroxinemia results in fetal growth retardation and impaired brain development before the onset of fetal thyroid function. Glucose uptake in fetal brain parenchyma may be compromised directly, due to deficient GLUT1 expression in this tissue, and indirectly, as a result of reduced placental GLUT1 expression. Though corrected by the onset of fetal thyroid hormone synthesis, these deficits are present during the critical period of neuroblast proliferation and may contribute to long term changes in brain development and function seen in this model and in the progeny of hypothyroxinemic women.

Journal of Endocrinology (1999) 163, 385-394

\section{Introduction}

Observations in humans and animal models are consistent with the hypothesis that maternal thyroid hormone regulates early fetal brain development (Porterfield \& Hendrich 1991, Morreale de Escobar et al. 1997, Pickard et al. 1997, Sinha et al. 1997). For example, children born to hypothyroxinemic mothers in certain iodine deficiency endemias - though themselves clinically euthyroiddisplay an increased incidence of neurologic disorders, ranging from subclinical deficits in cognitive and motor function to overt neurologic cretinism (Connolly \& Pharoah 1989). These disorders can be prevented by iodine supplementation, but only if administered well before the onset of fetal thyroid function, and cognitive and motor function in affected children has been shown to correlate with maternal thyroxine (T4) levels during pregnancy (Connolly \& Pharoah 1989). Associations between maternal hypothyroxinemia and impaired motor and intellectual development have also been reported in iodine-sufficient environments (Man et al. 1991).

Studies in the rat have shown that maternal thyroidectomy impairs fetal somatic and brain growth (Morreale de
Escobar et al. 1985, Bonet \& Herrera 1988, Porterfield \& Hendrich 1991, Pickard et al. 1993). Such deficits are corrected following the onset of fetal thyroid function in a hypothyroxinemic rat dam model, but sensitive markers of brain cell maturation - such as ornithine decarboxylase and neurotransmitter metabolic enzymes - remain abnormal in postnatal life (Pickard et al. 1993, Evans et al. 1999). Biochemical dysfunction is generally confined to early developing brain regions and is associated with learning and motor deficits in adult progeny (Pickard et al. 1997).

Maternal T4 is transferred to the developing conceptus during pregnancy in humans and rats (Porterfield \& Hendrich 1991, Morreale de Escobar et al. 1997, Pickard et al. 1997, Sinha et al. 1997). Although the amount transferred constitutes only a small fraction of the maternal circulating pool, T4 and metabolites (in particular 3,5,3'triiodothyronine; T3) accumulate within the developing brain before the onset of fetal thyroid activity, coincident with nuclear T3 receptor expression. Fetal brain total T3 levels are low (ca. $100 \mathrm{pM}$ ) at this time (Ferreiro et al. 1988, Ruiz de Ona et al. 1988), but receptor occupancy approximates $25 \%$ since free $\mathrm{T} 3$ concentrations are high in the nucleus relative to the cytosol (Ferreiro et al. 1988). 
Maternal thyroid hormone may therefore directly influence early fetal brain development, however because it also accumulates within maternal tissues and the placenta (Morreale de Escobar et al. 1985), indirect mechanisms of regulation may be important. Placental maldevelopment has been reported in some (Bonet \& Herrera 1988, Porterfield \& Hendrich 1991) - but not all (Morreale de Escobar et al. 1985)-hypothyroid rat dam models, whereas gross placental growth is normal in hypothyroxinemic dams (Pickard et al. 1993). More subtle disturbances in placental function cannot be ruled out however.

Thyroid hormone regulates glucose transport in astrocytes in culture (Roeder et al. 1988) and postnatal rat brain in vivo (Moore et al. 1973). Such findings are likely to be of relevance to maternal thyroid hormone action since the fetus is highly dependent upon glucose, both as an energy source and as a precursor for biosynthetic reactions intimately connected with tissue growth (Jones \& Rolph 1985). In the rat, the fetal glucose supply is derived from the maternal circulation (Jones \& Rolph 1985), with placental transfer of glucose and uptake into fetal tissues being mediated by facilitative glucose transporters (GLUT) (Burant et al. 1991, Mueckler 1994). GLUT isoforms exhibit distinct developmental- and tissuespecific patterns of expression, GLUT1 and GLUT3 together serving as the major glucose transporters of rat placenta and brain (Burant et al. 1991, Mueckler 1994).

We have therefore examined the influence of maternal hypothyroxinemia in the rat on the ontogeny of GLUT1 and GLUT3 proteins in fetal brain and placenta. We demonstrate that maternal hypothyroxinemia results in reduced expression of GLUT1 protein in fetal brain and, to a lesser extent, placenta before the onset of fetal thyroid hormone synthesis. In contrast, the expression of GLUT3 protein is normal in fetal brain but shows a tendency towards increased levels in placenta. Nevertheless, fetal serum glucose levels are reduced at this stage of pregnancy. The effects on GLUT1 protein expression occur in the absence of changes in transcript levels in fetal brain and placenta, indicating the involvement of translational or post-translational mechanisms of regulation.

\section{Materials and Methods}

\section{Materials}

Polyclonal antibodies, raised against the C-terminal 13 amino acids of rat GLUT1 and GLUT3, were from Charles River (Southbridge, MA, USA); the GLUT3 antibody was supplied affinity-purified. Oligonucleotides were synthesized by Genosys Biotechnologies (Cambridge, Cambs, UK). Plasmid pSGT containing human GLUT1 cDNA was from the ATCC (Rockville, $\mathrm{MD}$, USA) and pBluescript II SK ${ }^{+}$from Stratagene Ltd (Cambridge, Cambs, UK). Restriction enzymes were from Promega (Southampton, Hants, UK) and PCR reagents from PE Applied Biosystems (Warrington, Cheshire, UK). The MAXIscript kit was supplied by AMS Biotechnology (Europe) Ltd (Witney, Oxon, UK). Megaprime DNA and 5 '-end labeling kits, Hybond-N and -ECL membranes, protein $\mathrm{A}(>30 \mathrm{mCi} / \mathrm{mg})$ and Rainbow protein molecular weight markers were from Amersham Life Science Ltd (Little Chalfont, Bucks, UK). RNA and DNA ladders were from Life Technologies Ltd (Paisley, Renfrewshire, UK). dCTP $(3000 \mathrm{Ci} / \mathrm{mmol})$, UTP $(800 \mathrm{Ci} / \mathrm{mmol})$ and ATP $(4500 \mathrm{Ci} / \mathrm{mmol})$ were from ICN Biomedicals Ltd (Thame, Oxon, UK). NICK columns and Microcon-30 microconcentrators were from Pharmacia Biotech (St Albans, Herts, UK) and Amicon Ltd (Stonehouse, Gloucs, UK) respectively. Total T4 and T3 RIA kits were from NETRIA (London, UK), glucose (Trinder) reagent from Sigma-Aldrich Company Ltd (Poole, Dorset, UK) and Coomassie Protein Plus reagent from Pierce \& Warriner (UK) Ltd (Chester, Cheshire, UK).

\section{Animal model}

Sprague-Dawley rats were maintained in local animal house facilities at $22^{\circ} \mathrm{C}$ on a cycle of $14 \mathrm{~h}$ light and $10 \mathrm{~h}$ darkness. Female rats were partially thyroidectomized (parathyroid-spared) by surgery and, after a recovery period of at least 2 weeks, time-mated with normal males when serum total T4 levels were $\leq 30 \mathrm{nM}$ (TX dams). Pregnant normal (untreated) females constituted the control group ( $\mathrm{N} \mathrm{dams).} \mathrm{Animals} \mathrm{had} \mathrm{free} \mathrm{access} \mathrm{to} \mathrm{water} \mathrm{and}$ food (standard small animal laboratory diet); the drinking water of TX dams was supplemented with $0 \cdot 1 \%$ calcium lactate. Animals were stunned then killed by cervical dislocation at 16, 19 or 21 days gestation (dg). Maternal blood was collected by cardiac puncture. Fetuses and placentae were separated on ice, weighed and whole brains quickly dissected. These were cleansed of adherent blood and meninges before weighing. In some experiments, fetal blood was collected from the neck stump after decapitation and pooled from each pregnancy. Other fetal and placental tissues from each litter were also pooled (three to four tissues/pool) before storage at $-20{ }^{\circ} \mathrm{C}$.

\section{Isolation of crude microsomes and Western blot analysis}

Placentae were chopped $\left(1 \mathrm{~mm}^{3}\right.$ pieces $)$ and washed three times with 9 vol ice-cold TES-PMSF $(50 \mathrm{mM}$ Tris-HCl, pH 7.4; 2 mM EDTA; 0.25 M sucrose; $1 \mathrm{mM}$ phenylmethylsulphonyl fluoride). Brains and washed placentae were homogenized with 4 vol TES-PMSF $\left(4^{\circ} \mathrm{C}\right)$ and centrifuged $\left(5000 \mathrm{~g} ; 5 \mathrm{~min} ; 4^{\circ} \mathrm{C}\right)$. The supernatant was further centrifuged $\left(104000 \mathrm{~g} ; 60 \mathrm{~min} ; 4^{\circ} \mathrm{C}\right)$ to collect the crude microsomal fraction. This pellet was washed once by centrifugation, resuspended in $0.7 \mathrm{vol}$ TES-PMSF and stored at $-20{ }^{\circ} \mathrm{C}$. 
Electrophoresis was performed using a standard method (Laemmli 1970). Microsomal fractions were diluted in TES-PMSF to the desired protein concentration, then diluted 1:1 with $2 \times$ reducing buffer and incubated at $37^{\circ} \mathrm{C}$ for $15 \mathrm{~min}$. Samples, including an adult brain control (13 $\mu \mathrm{g}$ microsomal protein), and molecular weight markers were electrophoresed (SDS-PAGE; 10\% gel) then transferred to Hybond-ECL membranes (Towbin et al. 1979). Blots were blocked with $4 \%$ BSA in TBS-T $(0 \cdot 1 \%$ Tween-20 in Tris-buffered saline, $\mathrm{pH} 7 \cdot 6$ ) for $1 \mathrm{~h}$ at $25^{\circ} \mathrm{C}$, washed in TBS-T and incubated with either an anti-GLUT1 or an anti-GLUT3 antibody (each diluted $1: 2000$ in $0.5 \%$ BSA in TBS-T) for $1 \mathrm{~h}$ at $25^{\circ} \mathrm{C}$. Blots were washed in TBS-T and incubated with protein $\mathrm{A}$ at $10 \mathrm{ng} / \mathrm{ml}$ in antibody diluent. After further washing in TBS-T, blots were exposed to pre-flashed film at $-70{ }^{\circ} \mathrm{C}$. Radioactive bands (and background control areas) were excised from the filters and counted by $\gamma$-spectrometry. Counts were corrected for background and decay, then further corrected for filter-to-filter variation by comparison of the counts for the adult brain control present on each blot.

\section{RNA isolation and Northern blot analysis}

Total RNA was isolated (Chomczynski \& Sacchi 1987) and aliquots $(20 \mu \mathrm{g})$ and size markers were electrophoresed $(1.2 \%$ agarose-formaldehyde gel), blotted on to Hybond-N membranes and UV-fixed. Blots were then hybridized with GLUT1 cDNA or antisense cRNA probes.

The cDNA probe comprised a $545 \mathrm{bp}$ fragment (nucleotides +846 to +1390 of human GLUT1) generated by PCR from the plasmid pSGT. The plasmid was linearized with SmaI and amplified with AmpliTaq DNA polymerase for 25 cycles. Sense and antisense primers were 5'-GCAGCTGTCTGGCAT-3' and 5'-CGATCTCAT CGAAGG-3' respectively; $\mathrm{MgCl}_{2}$ was $2.5 \mathrm{mM}$ and annealing temperature $41^{\circ} \mathrm{C}$. The probe was partially purified (Microcon-30) and radiolabeled using dCTP and the Megaprime DNA labeling system; non-incorporated nucleotide was removed using a NICK column. For generation of the riboprobe, pSGT was digested with XhoII and EcoRI and a 1244 bp fragment (nucleotides +279 to +1476 of human GLUT1 plus a portion of the 3 '-untranslated region) subcloned into the BamHI/EcoRI sites of pBluescript II $\mathrm{SK}^{+}$. Radiolabeled probe was produced by in vitro transcription of XhoI-linearized plasmid using T3 RNA polymerase and UTP. Radiolabeled riboprobe was purified by precipitation in ethanolammonium acetate.

For hybridization with the cDNA probe, blots were prehybridized for $8 \mathrm{~h}$ at $42{ }^{\circ} \mathrm{C}$ with $6 \times \mathrm{SSPE} ; 5 \times$ Denhardt's; $0 \cdot 5 \%$ SDS; $50 \mu \mathrm{g} / \mathrm{ml}$ salmon testis DNA; $50 \%$ formamide, then hybridized for $16 \mathrm{~h}$ at $42{ }^{\circ} \mathrm{C}$ with radiolabeled probe at ca. $10^{7}$ c.p.m. $/ \mathrm{ml}$ in $6 \times \mathrm{SSPE} ; 10 \%$ dextran sulphate; $2 \times$ Denhardt's; $0 \cdot 1 \%$ SDS; $20 \mu \mathrm{g} / \mathrm{ml}$ salmon testis DNA; 50\% formamide. For riboprobes, blots were prehybridized for $8 \mathrm{~h}$ at $60^{\circ} \mathrm{C}$ in $5 \times \mathrm{SSPE}$; $2 \times$ Denhardt's; $0 \cdot 1 \%$ SDS; $100 \mu \mathrm{g} / \mathrm{ml}$ salmon testis DNA and $100 \mu \mathrm{g} / \mathrm{ml}$ bakers yeast tRNA; 50\% formamide, then hybridized for $16 \mathrm{~h}$ at $60{ }^{\circ} \mathrm{C}$ with fresh solution containing radiolabeled probe at ca. $2 \times 10^{6}$ c.p.m. $/ \mathrm{ml}$.

Hybridized blots were subjected to a final high stringency wash for $20 \mathrm{~min}$ in $0 \cdot 1 \times \mathrm{SSC} / 0 \cdot 1 \% \mathrm{SDS}$ at $55^{\circ} \mathrm{C}$ (cDNA probe) or $75^{\circ} \mathrm{C}$ (riboprobe), then exposed to preflashed film with an intensifying screen at $-70{ }^{\circ} \mathrm{C}$. All blots were stripped and rehybridized with an oligonucleotide probe to nucleotides +292 to +321 of rat 18 S rRNA, as loading control (Varghese et al. 1994). Hybridization was performed at $68^{\circ} \mathrm{C}$ in $6 \times \mathrm{SSPE} ; 5 \times$ Denhardt's and $50 \mu \mathrm{g} / \mathrm{ml}$ salmon testis DNA. The probe was $5^{\prime}$-endlabeled with ATP, purified (NICK column), then added to hybridization solution at $1 \mathrm{nM}$ (specific activity $10^{6}$ d.p.m. $/ \mathrm{pmol}$ ). The final high stringency wash was in $6 \times \mathrm{SSPE} / 0 \cdot 1 \% \operatorname{SDS}$ at $78{ }^{\circ} \mathrm{C}$ for $2 \mathrm{~min}$.

Autoradiographs were digitized using a Kodak DC-40 digital camera. Densitometric analysis was by $\mathrm{NIH}$ Image version 6.1 using an optical density step tablet for calibration.

\section{Determination of thyroid hormone}

Total T4 and total T3 levels were determined in maternal serum by RIA using commercial kits.

\section{Determination of glucose}

Glucose was determined in maternal and fetal serum by the method of Trinder (1969).

\section{Protein determination}

Protein was determined by a dye-binding method (Bradford 1976) using commercial reagents.

\section{Statistical analysis}

Data from $\mathrm{N}$ and TX dam pregnancies were compared by two-way ANOVA for age and treatment effects; Fisher's protected least significant differences (PLSD) were determined for the post-hoc analysis. Homogeneity of variance for all groups was checked using Bartlett's test for samples of unequal sizes and, where necessary, a square root or log transformation was applied before analysis. All results were consistent with a Gaussian distribution and are expressed as mean \pm S.E.M.

\section{Results}

\section{Animal model}

Premating serum total T4 levels were similar in TX dams irrespective of whether these were studied at 16, 19 or 
Table 1 Maternal serum thyroid hormone levels, litter size and feto-placental growth in euthyroid (N) and partially thyroidectomized (TX) rat dam pregnancies

\begin{tabular}{|c|c|c|c|c|c|c|c|}
\hline & \multirow[b]{2}{*}{ Dam } & \multirow[b]{2}{*}{$\begin{array}{l}\text { Maternal T4 } \\
(\mathrm{nM})\end{array}$} & \multirow[b]{2}{*}{$\begin{array}{l}\text { Maternal T3 } \\
(\mathrm{nM})\end{array}$} & \multirow[b]{2}{*}{ Litter size } & \multicolumn{3}{|c|}{ Tissue weight } \\
\hline & & & & & $\begin{array}{l}\text { Fetal body } \\
(\mathrm{mg})\end{array}$ & $\begin{array}{l}\text { Fetal brain } \\
(\mathrm{mg})\end{array}$ & $\begin{array}{l}\text { Placenta } \\
\text { (mg) }\end{array}$ \\
\hline \multirow[t]{2}{*}{16} & $\mathrm{~N}$ & $44 \cdot 0 \pm 2 \cdot 6$ & $1 \cdot 51 \pm 0 \cdot 24$ & $17 \cdot 0 \pm 0 \cdot 6$ & $493 \pm 9$ & $52 \cdot 6 \pm 1 \cdot 1$ & $344 \pm 13$ \\
\hline & $\mathrm{TX}$ & $13 \cdot 9 \pm 1 \cdot 6^{b}$ & $0 \cdot 94 \pm 0 \cdot 22^{a}$ & $11 \cdot 9 \pm 0.9^{b}$ & $445 \pm 9^{b}$ & $48 \cdot 7 \pm 1 \cdot 5^{a}$ & $339 \pm 17$ \\
\hline 19 & $\mathrm{~N}$ & $29 \cdot 9 \pm 1 \cdot 7$ & $1 \cdot 33 \pm 0 \cdot 17$ & $16 \cdot 4 \pm 1 \cdot 0$ & $2190 \pm 38$ & $127 \cdot 5 \pm 1 \cdot 9$ & $497 \pm 13$ \\
\hline 21 & TX & $11 \cdot 6 \pm 1 \cdot 1^{\mathrm{b}}$ & $0 \cdot 91 \pm 0 \cdot 23^{a}$ & $12 \cdot 1 \pm 1 \cdot 0^{\mathrm{b}}$ & $4925 \pm 97$ & $185 \cdot 0 \pm 2 \cdot 2$ & $570 \pm 14$ \\
\hline \multicolumn{8}{|c|}{ Two-way ANOVA } \\
\hline Treatment & $P$ & $<0.001$ & $<0.001$ & $<0.001$ & $<0.005$ & NS & NS \\
\hline $\begin{array}{l}\text { Age-treatment } \\
\text { interaction }\end{array}$ & $P$ & $<0.001$ & NS & NS & NS & NS & NS \\
\hline
\end{tabular}

NS, No significant difference by two-way ANOVA. ${ }^{a} P<0 \cdot 05 ;{ }^{b} P<0 \cdot 001 ;$ TX vs $N$ dam pregnancy at the appropriate age (Fisher's PLSD test) $n \geq 13$ different dams.

$21 \mathrm{dg}$ (values were: $16 \cdot 6 \pm 1 \cdot 8 \mathrm{nM}, 16 \cdot 3 \pm 1 \cdot 6 \mathrm{nM}$ and $17 \cdot 7 \pm 1 \cdot 3 \mathrm{nM}$ respectively; $n \geq 14)$; each being reduced (by ca. $70 \% ; \quad P<0.001$ ) when compared with nonpregnant euthyroid controls (values were: $57 \cdot 0 \pm 1 \cdot 9 \mathrm{nM}$ ). A similar reduction was found in pregnant animals at $16 \mathrm{dg}$ (Table 1). Differences between N and TX dams were less marked at subsequent stages of pregnancy, since circulating total T4 levels declined in $\mathrm{N}$ dams, as expected (Morreale de Escobar et al. 1985), but remained relatively stable in TX dams (Table 1). Maternal serum total T3 levels remained invariant over the study period, and were reduced by approximately $40 \%$ in TX dams (Table 1 ).

Litter size was consistently reduced by $30 \%$ in TX dams at 16-21 dg (Table 1). Fetal body weight was reduced by $10 \%$ in TX dams at $16 \mathrm{dg}$ but was normal at subsequent stages of pregnancy (Table 1); a similar pattern was observed for fetal brain weight (Table 1). Placental weight was normal at all stages of pregnancy studied (Table 1).

Although the concentration of total protein in fetal brain from TX dams was normal between 16 and $21 \mathrm{dg}$, the proportion of protein recovered in the crude microsomal fraction appeared deficient (Table 2). Post-hoc analysis confirmed a significant reduction at $16 \mathrm{dg}$ (68\% control level). In TX dam placenta, the concentration of total protein was reduced at $19 \mathrm{dg}$ to $80 \%$ of the control level (Table 2).

\section{GLUT1 protein expression}

Irrespective of maternal thyroid status, GLUT1 species of 44 and $51 \mathrm{kDa}$ were detected in fetal brain microsomes at $16-21 \mathrm{dg}$, whereas only the $44 \mathrm{kDa}$ form was observed in

Table 2 Total and microsomal protein in fetal brain and placenta from euthyroid $(\mathrm{N})$ and partially thyroidectomized (TX) rat dam pregnancies

\begin{tabular}{|c|c|c|c|c|c|}
\hline & \multirow[b]{2}{*}{ Dam } & \multicolumn{2}{|c|}{ Fetal brain protein } & \multicolumn{2}{|c|}{ Placental protein } \\
\hline & & $\begin{array}{l}\text { total } \\
\text { (mg/g tissue) }\end{array}$ & $\begin{array}{l}\text { microsomal } \\
\text { (\% total) }\end{array}$ & $\begin{array}{l}\text { total } \\
\text { (mg/g tissue) }\end{array}$ & $\begin{array}{l}\text { microsomal } \\
\text { (\% total) }\end{array}$ \\
\hline \multicolumn{6}{|l|}{ Days gestation } \\
\hline \multirow[t]{2}{*}{16} & $\mathrm{~N}$ & $51 \cdot 3 \pm 1 \cdot 8$ & $13 \cdot 8 \pm 1 \cdot 0$ & $67 \cdot 7 \pm 3 \cdot 0$ & $14 \cdot 0 \pm 1 \cdot 9$ \\
\hline & TX & $53 \cdot 0 \pm 3 \cdot 6$ & $9 \cdot 4 \pm 1 \cdot 1^{\mathrm{a}}$ & $66 \cdot 6 \pm 4 \cdot 8$ & $12 \cdot 9 \pm 0 \cdot 9$ \\
\hline \multirow[t]{2}{*}{19} & $\mathrm{~N}$ & $54 \cdot 5 \pm 2 \cdot 5$ & $13 \cdot 7 \pm 1 \cdot 4$ & $79 \cdot 3 \pm 6 \cdot 3$ & $10 \cdot 3 \pm 0 \cdot 6$ \\
\hline & $\mathrm{TX}$ & $56 \cdot 1 \pm 2 \cdot 2$ & $12 \cdot 2 \pm 1 \cdot 3$ & $62 \cdot 9 \pm 5 \cdot 6^{b}$ & $10 \cdot 9 \pm 1 \cdot 1$ \\
\hline \multirow[t]{2}{*}{21} & $\mathrm{~N}$ & $53 \cdot 6 \pm 3 \cdot 2$ & $19 \cdot 3 \pm 1 \cdot 9$ & $59 \cdot 5 \pm 4 \cdot 7$ & $13 \cdot 0 \pm 1 \cdot 3$ \\
\hline & $\mathrm{TX}$ & $56 \cdot 9 \pm 2 \cdot 1$ & $15 \cdot 1 \pm 1 \cdot 9$ & $69 \cdot 7 \pm 2 \cdot 5$ & $11 \cdot 5 \pm 0 \cdot 7$ \\
\hline \multicolumn{6}{|c|}{ Two-way ANOVA } \\
\hline \multirow{2}{*}{$\begin{array}{l}\text { Treatment } \\
\text { Age-treatment }\end{array}$} & $P$ & NS & $<0.01$ & NS & NS \\
\hline & $P$ & NS & NS & $<0.05$ & NS \\
\hline
\end{tabular}

NS, No significant difference by two-way ANOVA. ${ }^{\mathrm{a}} \mathrm{P}<0 \cdot 05 ;{ }^{\mathrm{b}} \mathrm{P}<0 \cdot 02 ; \mathrm{TX}$ vs $\mathrm{N}$ dam pregnancy at the appropriate age (Fisher's PLSD test) $n \geq$ six different dams. 
A

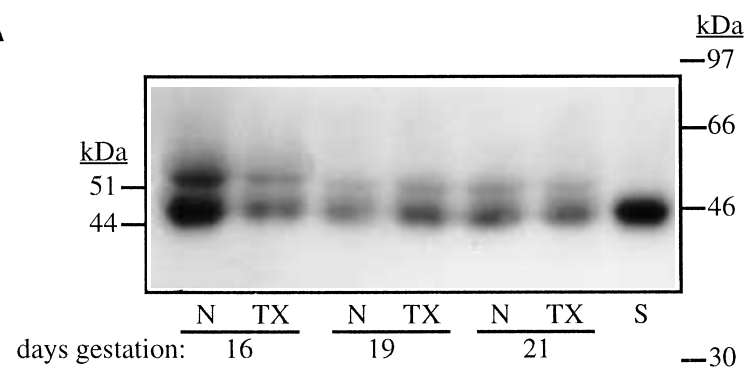

B

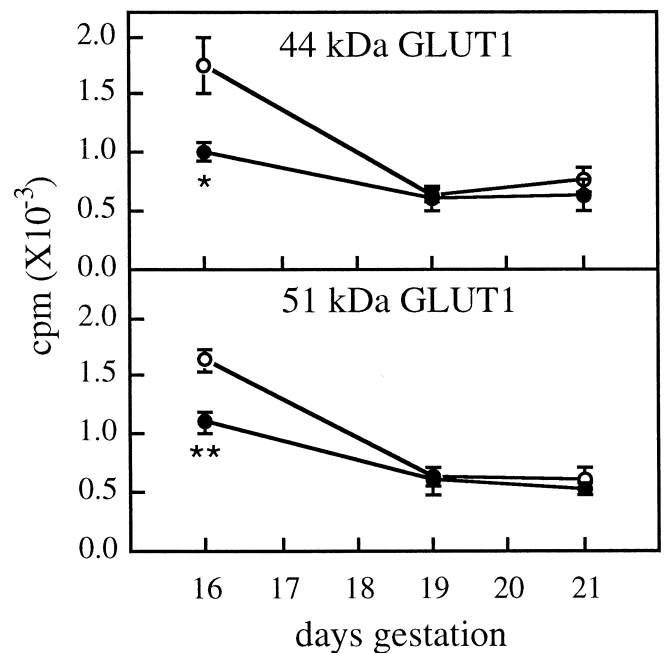

Figure 1 Effect of maternal hypothyroxinemia on GLUT1 protein expression in fetal brain. A, Western blot of fetal brain microsomes (50 $\mu$ g protein) from normal $(\mathrm{N})$ and partially thyroidectomized (TX) rat dams immunodetected with a GLUT1-specific antibody and protein A. Blots also included an adult brain microsomal standard ( $S ; 13 \mu$ g protein). Only a portion of the autoradiogram is shown and the migration of molecular weight markers is indicated on the right hand side. Note the presence in fetal brain of discrete 44 and $51 \mathrm{kDa}$ species. B, Radioactive bands were excised from filters and counted. Counts were background-subtracted and corrected for filter-to-filter variation using the adult brain standard. Each point is the mean corrected c.p.m. \pm S.E.M. of seven different $N(\bigcirc)$ or TX $(0)$ dams. Significant treatment effects were found for both $51 \mathrm{kDa}(P<0 \cdot 05)$ and $44 \mathrm{kDa}(P<0 \cdot 02)$ forms. ${ }^{*} P<0 \cdot 01$; ${ }^{* *} P<0 \cdot 005$; TX vs $\mathrm{N}$ dam at the appropriate age (Fisher's PLSD test).

adult brain microsomes (Fig. 1). These forms arise by differential glycosylation of a $37 \mathrm{kDa}$ precursor (Wang \& Brennan 1988) and are thought to be derived from the brain parenchyma (Walker et al. 1988, Wang \& Brennan 1988, Dermietzel et al. 1992, Vannucci 1994).

In normal fetal brain, the microsomal abundance of the two GLUT1 forms declined between 16 and $19 \mathrm{dg}$ and then remained stable (Fig. 1). Maternal thyroidectomy resulted in deficient expression of both $44 \mathrm{kDa}(58 \%$ control level) and $51 \mathrm{kDa}(67 \%$ control level) GLUT1 at $16 \mathrm{dg}$, although levels of both were normal at 19 and $21 \mathrm{dg}$ (Fig. 1). When age- and treatment-related effects on fetal brain microsomal protein were taken into account - by expressing results as a tissue concentration-more pronounced deficits in 44 and $51 \mathrm{kDa}$ GLUT1 (40 and 47\% control levels respectively) were seen at $16 \mathrm{dg}$ (data not shown).

The GLUT1 antibody detected a discrete $44 \mathrm{kDa}$ species in placental microsomes as well as 58 and $64 \mathrm{kDa}$ species (Fig. 2). It has previously been noted that rat placental GLUT1 exhibits heterogeneous molecular mass due to variable glycosylation (Boileau et al. 1995, Shin et al. 1997). In normal placenta, levels of total GLUT1 protein increased over the period studied, but the constituent $44 \mathrm{kDa}$ and hyperglycosylated forms exhibited distinct ontogenic profiles (Fig. 2). The abundance of the $44 \mathrm{kDa}$ form remained stable between 16 and $19 \mathrm{dg}$, then doubled by $21 \mathrm{dg}$, whereas the hyperglycosylated species increased steadily (3·4-fold) over the study period (Fig. 2). Similar ontogenic profiles were observed in placenta from TX dams, with significant overall treatment effects found for the hyperglycosylated and total transporter forms, though post-hoc analysis confirmed only a significant difference for the abundance of total transporter $(72 \%$ control level) at $16 \mathrm{dg}$ (Fig. 2).

When placental GLUT1 levels were expressed as a function of tissue wet weight, similar ontogenic profiles were obtained but statistically significant treatment-related differences were observed for total $(P=0.004), 44 \mathrm{kDa}$ $(P=0.030)$ and hyperglycosylated $(P=0.008)$ forms. Posthoc analysis showed significant $(P<0 \cdot 05)$ reductions in TX dam placental concentrations of total transporters at $16 \mathrm{dg}$ $\left(8 \cdot 2 \pm 1 \cdot 1\right.$ vs $11 \cdot 8 \pm 0 \cdot 8 \times 10^{6}$ c.p.m./g for controls $)$ and $19 \mathrm{dg}\left(12 \cdot 8 \pm 1 \cdot 2\right.$ vs $19 \cdot 3 \pm 2.6 \times 10^{6}$ c.p.m./g for controls), and of hyperglycosylated forms at $19 \mathrm{dg}(5 \cdot 2 \pm 0 \cdot 8$ vs $8.5 \pm 1.5 \times 10^{6}$ c.p.m./g for controls).

\section{GLUT3 protein expression}

The GLUT3 antibody recognized two protein species in fetal and adult brain microsomes (Fig. 3). The major $48 \mathrm{kDa}$ species corresponds to authentic GLUT3 protein, while the minor $44 \mathrm{kDa}$ band is thought to arise from cross-reaction with actin (Shepherd et al. 1992). The abundance of $48 \mathrm{kDa}$ GLUT3 protein increased steadily in normal fetal brain between 16 and $19 \mathrm{dg}$, and 19 and $21 \mathrm{dg}(P<0 \cdot 05$; Fisher's PLSD test), whereas no increase was noted after $19 \mathrm{dg}$ in TX dams (Fig. 3). A similar difference was apparent when brain GLUT3 levels were expressed as a tissue concentration (data not shown), but treatment and age-treatment interaction effects failed to achieve statistical significance irrespective of the method of expressing results.

In placenta, the GLUT3 antibody recognized slower migrating species $(55-87 \mathrm{kDa})$ in addition to the $48 \mathrm{kDa}$ form noted in brain (Fig. 4). In contrast to GLUT1, the expression of the $48 \mathrm{kDa}$ and hyperglycosylated GLUT3 forms appeared co-ordinately regulated in normal 
pregnancy; the abundance of all forms progressively increased between 16 and $21 \mathrm{dg}$ (Fig. 4). Furthermore, the hyperglycosylated forms were expressed at higher levels than the $48 \mathrm{kDa}$ form. Similar findings have been reported by other investigators (Boileau et al. 1995, Shin et al. 1997). Maternal hypothyroxinemia was without overall effect on the expression of total and hyperglycosylated placental GLUT3 (Fig. 4 and data not shown), though

A

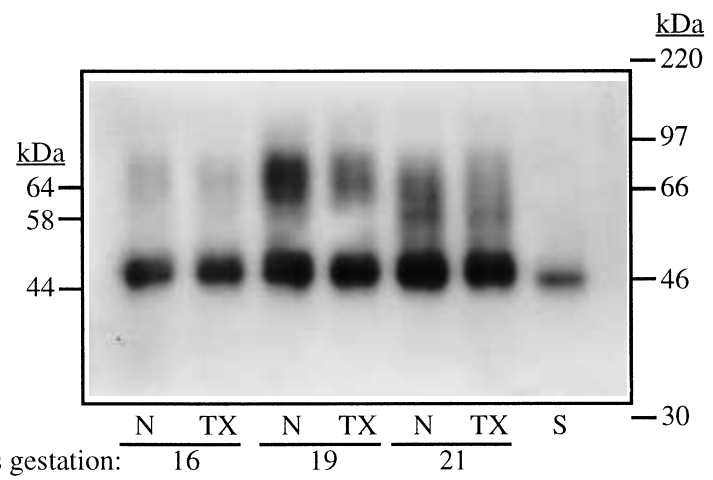

B

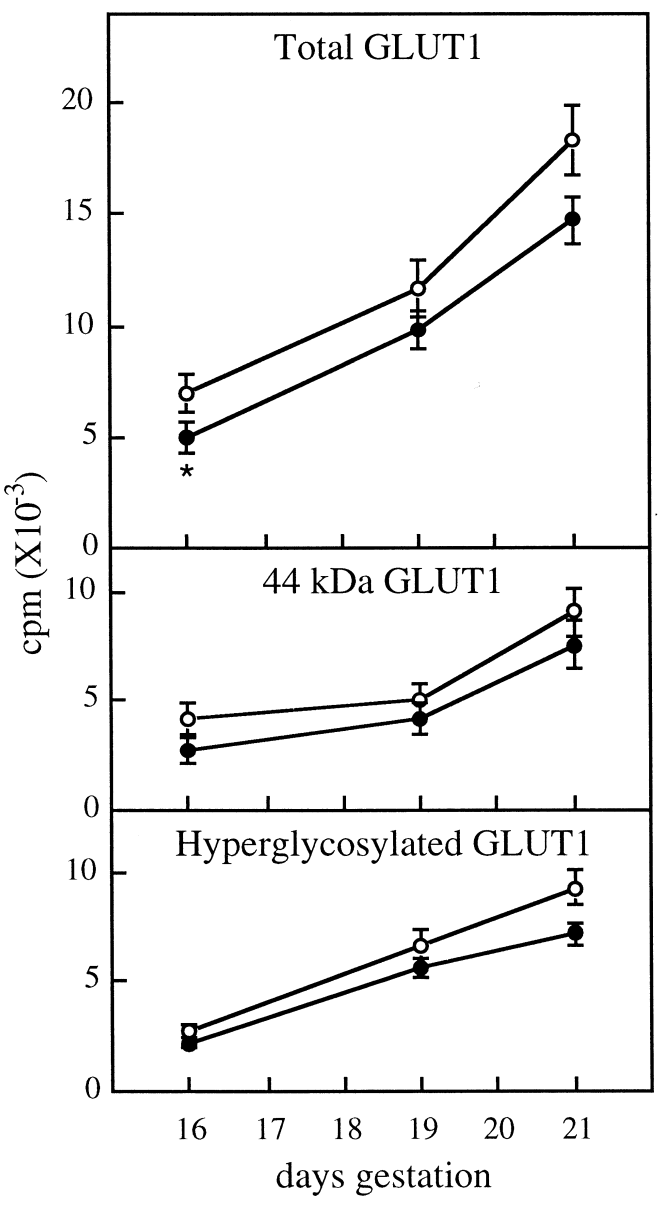

age-treatment interaction approached statistical significance for $48 \mathrm{kDa}$ GLUT3; post-hoc analysis confirmed that this species was significantly elevated (144\% control level) in TX dam placenta at $16 \mathrm{dg}$ (Fig. 4). When results were expressed as a tissue concentration, significant agetreatment interaction $(P=0.046)$ was noted for the $48 \mathrm{kDa}$ form although no significant differences were found at any individual age by post-hoc analysis (data not shown).

\section{GLUT1 mRNA expression}

In further experiments, we examined whether maternal hypothyroxinemia modulated GLUT1 transcript levels. This treatment had no effect on the yield of total RNA from fetal brain and placenta at any age (data not shown), allowing a control $18 \mathrm{~S}$ rRNA probe to be used to correct for differences in sample loading.

Hybridization of Northern blots containing total RNA from placenta, fetal brain and adult brain revealed the presence of a $2.7 \mathrm{~kb}$ transcript in all tissues and a minor $1.6 \mathrm{~kb}$ transcript in placenta alone (data not shown). This latter transcript was also evident on blots containing poly $(\mathrm{A})^{+}$placental RNA and was attenuated coincident with the $2 \cdot 7 \mathrm{~kb}$ signal when hybridized blots were washed at increasing stringency (data not shown), indicating that it may represent a splice variant or closely related transcript. Levels of the $2.7 \mathrm{~kb}$ transcript were markedly higher in placenta than in adult brain, but barely detectable in fetal brain. Consequently, a riboprobe was utilized to assess the effects of maternal thyroidectomy on fetal brain GLUT1 mRNA expression.

Expression of the $2.7 \mathrm{~kb}$ GLUT1 transcript was developmentally regulated in fetal brain in both $\mathrm{N}$ and TX dam pregnancies (Fig. 5), with levels decreasing between 16 and $19 \mathrm{dg}(P<0 \cdot 01$, for both groups; post-hoc analysis). Maternal hypothyroxinemia was without any significant effect on fetal brain GLUT1 expression at any age (Fig. 5). Hybridization analysis of Northern blots of placental total RNA with the GLUT1 cDNA probe revealed no

Figure 2 Effect of maternal hypothyroxinemia on GLUT1 protein expression in placenta. A, Western blot of placental microsomes (5 $\mu$ g protein) from normal $(\mathrm{N})$ and partially thyroidectomized (TX) rat dams immunodetected with a GLUT1-specific antibody and protein A. Blots also included an adult brain microsomal standard (S; $13 \mu$ g protein). Only a portion of the autoradiogram is shown and the migration of molecular weight markers is indicated on the right hand side. Note the presence in placenta of 44, 58 and $64 \mathrm{kDa}$ species. B, Radioactive bands corresponding to $44 \mathrm{kDa}$ GLUT1 and hyperglycosylated forms (58 and 64 kDa GLUT1 together) were excised from filters and counted. Counts were background-subtracted and corrected for filter-to-filter variation using the adult brain standard. Each point is the mean corrected c.p.m. \pm S.E.M. of at least six different $\mathrm{N}(\bigcirc)$ or $\mathrm{TX}(\mathbf{O})$ dams. Significant treatment effects were found for total transporters $(P<0 \cdot 02)$ and hyperglycosylated forms $(P<0 \cdot 01)$. ${ }^{*} P<0 \cdot 05$; TX vs $N$ dam at the appropriate age (Fisher's PLSD test). 
A

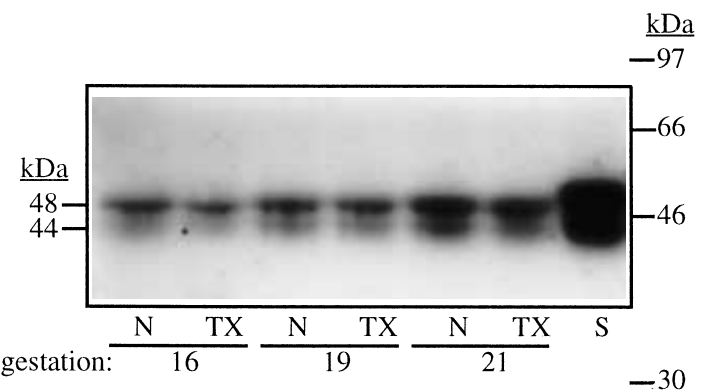

$\mathrm{B}$

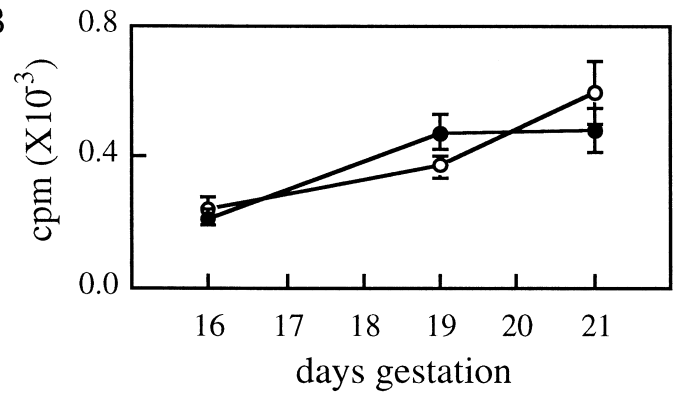

Figure 3 Effect of maternal hypothyroxinemia on GLUT3 protein expression in fetal brain. A, Western blot of fetal brain microsomes (50 $\mu$ g protein) from normal $(\mathrm{N})$ and partially thyroidectomized (TX) rat dams immunodetected with a GLUT3-specific antibody and protein A. Blots also included an adult brain microsomal standard ( $S ; 13 \mu \mathrm{g}$ protein). Only a portion of the autoradiogram is shown and the migration of molecular weight markers is indicated on the right hand side. Note the presence in fetal brain of discrete $44 \mathrm{kDa}$ (cross-reacting actin) and $48 \mathrm{kDa}$ (authentic GLUT3) species. B, Radioactive bands corresponding to 48 kDa GLUT3 were excised from filters and counted. Counts were background-subtracted and corrected for filter-to-filter variation using the adult brain standard. Each point is the mean corrected c.p.m. \pm S.E.M. of seven different $\mathrm{N}(\mathrm{O})$ or $\mathrm{TX}(\mathbf{)})$ dams. No significant treatment or age-treatment interaction effects were found.

significant age- or treatment-related effects for the $2.7 \mathrm{~kb}$ transcript (Fig. 5). The placental $1.6 \mathrm{~kb}$ band was of low abundance and appeared invariant, and was therefore not quantified.

\section{Maternal and fetal serum glucose levels}

Finally, in a further batch of animals, we examined the influence of maternal hypothyroxinemia on fetal serum glucose levels. Glucose was also determined in maternal serum samples from these pregnancies as well as those used in the studies of GLUT protein and mRNA expression. Maternal glucose levels $(n=12$ dams) were found to be normal in TX dams at $16 \mathrm{dg}(6.69 \pm 0 \cdot 31$ vs $7 \cdot 12 \pm 0 \cdot 31 \mathrm{mM}), 19 \mathrm{dg}(6 \cdot 75 \pm 0 \cdot 34$ vs $6 \cdot 74 \pm 0 \cdot 18$ $\mathrm{mM})$ and $21 \mathrm{dg}(6 \cdot 10 \pm 0.38$ vs $5.65 \pm 0 \cdot 25 \mathrm{mM})$. In contrast, fetal serum glucose levels showed significant age-treatment interaction $(P=0 \cdot 036 ; n=8$ different
A

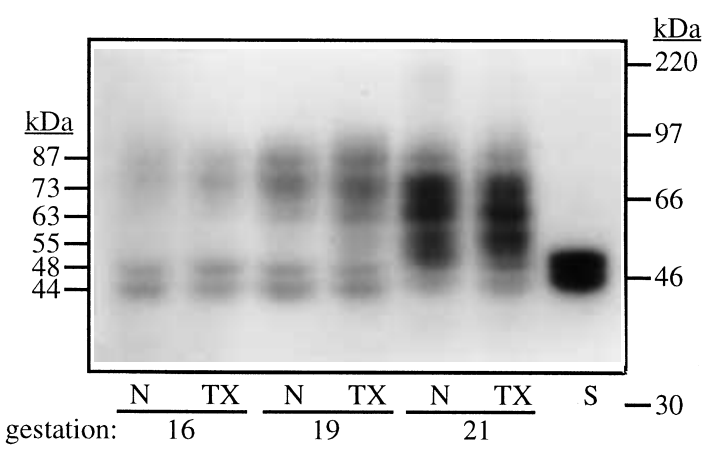

B

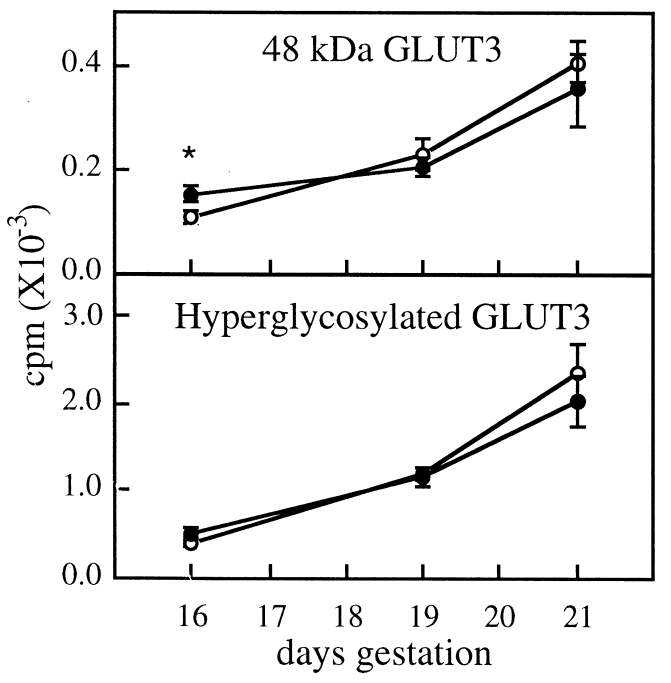

Figure 4 Effect of maternal hypothyroxinemia on GLUT3 protein expression in placenta. A, Western blot of placental microsomes (25 $\mu$ g protein) from normal $(\mathrm{N})$ and partially thyroidectomized (TX) rat dams immunodetected with a GLUT3-specific antibody and protein A. Blots also included an adult brain microsomal standard (S; $13 \mu \mathrm{g}$ protein). Only a portion of the autoradiogram is shown and the migration of molecular weight markers is indicated on the right hand side. Note the presence in placenta of multiple species; estimated sizes are indicated on the left hand side of the autoradiogram. The $44 \mathrm{kDa}$ species is thought to arise from cross-reaction of the antibody with actin. B, Radioactive bands corresponding to $48 \mathrm{kDa}$ GLUT3 and the collection of slower migrating species (hyperglycosylated forms) were excised from filters and counted. Counts were background-subtracted and corrected for filter-to-filter variation using the adult brain standard. Each point is the mean corrected c.p.m. \pm S.E.M. of at least six different $N(O)$ or TX $(\mathbf{O})$ dams. No significant treatment or age-treatment interaction (though $P=0.053$ for $48 \mathrm{kDa}$ GLUT3) effects were found. ${ }^{*} P<0 \cdot 05$; TX vs $\mathrm{N}$ dam at the appropriate age (Fisher's PLSD test).

pregnancies); post-hoc analysis confirmed a significant $(P<0 \cdot 05)$ reduction in serum levels in TX dam pregnancies at $16 \mathrm{dg}(1.66 \pm 0.13$ vs $2 \cdot 18 \pm 0 \cdot 21 \mathrm{mM})$, but not at $19 \mathrm{dg}(1.54 \pm 0.11$ vs $1.31 \pm 0.15 \mathrm{mM})$ or $21 \mathrm{dg}(4 \cdot 60 \pm 0 \cdot 40$ vs $4 \cdot 91 \pm 0 \cdot 18 \mathrm{mM})$. 


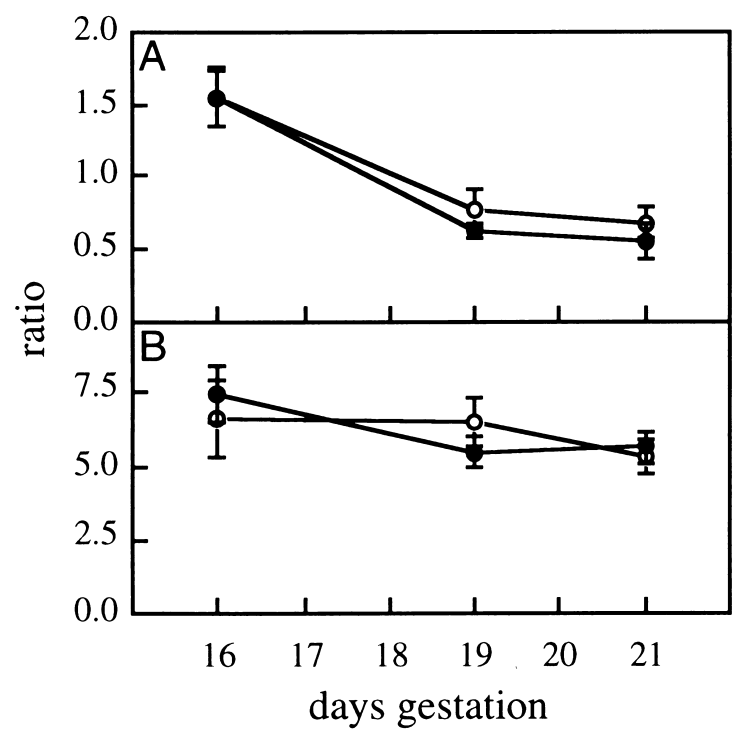

Figure 5 Effect of maternal hypothyroxinemia on GLUT1 mRNA expression in fetal brain and placenta. Northern blots of fetal brain and placental total RNA were hybridized sequentially with GLUT1 and $18 \mathrm{~S}$ rRNA probes. Ontogenic profiles for A, fetal brain and B, placenta are shown, where each point is the mean GLUT1/18S signal ratio \pm S.E.M. of at least four different normal $(\bigcirc)$ or partially thyroidectomized $(\bullet)$ dams. No significant treatment or age-treatment interaction effects were found.

\section{Discussion}

Female rats were partially thyroidectomized, then allowed at least 2 weeks recovery before mating. Maternal serum total T4 levels were reduced by $60 \%$ before the onset of fetal thyroid hormone synthesis, but total T3 levels were less severely affected ( $40 \%$ reduction); consequently these dams are termed 'hypothyroxinemic'. Though not measured here, maternal serum TSH levels are markedly elevated in this model (Evans et al. 1999). Because these TX dams are free from factors such as iodine deficiency and anti-thyroid drugs which directly impinge upon fetal thyroid function, the influence of maternal thyroid dysfunction per se on feto-placental development can be investigated. Thyroid hormone deficits in the fetus will therefore be greatest prior to the onset of fetal thyroid activity at 17-18 dg (Morreale de Escobar et al. 1985).

Maternal hypothyroxinemia reduced litter size and impaired fetal growth before the onset of fetal thyroid function, but placental weight remained normal, confirming previous observations in this model (Pickard et al. 1993, Evans et al. 1999). In fetal brain, the total protein concentration was normal, as previously noted (Pickard et al. 1993, Evans et al. 1999), but the microsomal protein concentration was deficient at $16 \mathrm{dg}$. This latter fraction is rather crude, and it is not yet known whether plasma membrane, intracellular membrane and/or mitochondrial constituents are affected. In placenta, deficits in the total protein concentration were seen at $19 \mathrm{dg}$, as noted earlier (Pickard et al. 1993). Maternal hypothyroxinemia also modified GLUT expression in placenta and fetal brain, independent of changes in tissue protein concentration. Thus, the microsomal abundance of GLUT1 protein was reduced in fetal brain and, to a lesser extent, placenta at $16 \mathrm{dg}$, whereas the $48 \mathrm{kDa}$ GLUT3 species was increased in placenta at this time. These changes were seen in the absence of changes in maternal serum glucose levels, as expected from studies of severely thyroid-deficient rat dams (Porterfield \& Hendrich 1991).

GLUT1 is more widely expressed in rat placenta than GLUT3. It is the only glucose transporter in the junctional zone (site of trophoblast proliferation) and is also expressed in the labyrinth, within the limiting membranes of the syncytial layers (barriers to the free diffusion of glucose across the placenta) (Zhou \& Bondy 1993, Boileau et al. 1995, Shin et al. 1997). Here it acts in concert with GLUT3 to mediate glucose uptake from maternal blood into syncytiotrophoblast layer I, but alone facilitates glucose efflux from syncytiotrophoblast layer II into the fetal circulation (Shin et al. 1997). Thus, even though the increase in GLUT3 expression in TX dam placenta at $16 \mathrm{dg}$ may serve to maintain, or even enhance, the intrasyncytial glucose concentration, the fetal glucose supply may be diminished if the GLUT1 deficit is present in syncytiotrophoblast layer II. Indeed, fetal serum glucose levels were reduced at this stage of gestation. Placental GLUT1 deficits may also result in aberrant glucose uptake in the junctional zone, although cytotrophoblast proliferation appears normal in this model (Pickard et al. 1993).

The 44 and $51 \mathrm{kDa}$ GLUT1 species detected in fetal brain microsomes are thought to constitute parenchymal transporters (Walker et al. 1988, Wang \& Brennan 1988, Vannucci 1994). Both forms are markedly deficient at $16 \mathrm{dg}$ in TX dam pregnancies, so that glucose uptake into neuronal and astrocytic cell precursors, choroid plexus epithelial cells or ependymal cells (Bondy et al. 1992, Dermietzel et al. 1992) may be reduced. Expression of the glucose transporter of differentiating neurons, GLUT3, is largely unaffected in contrast, though fetal hypoglycemia may impact upon cellular glucose uptake throughout the brain at $16 \mathrm{dg}$. Glucose restriction in early brain development may explain the transient deficit in brain cell number seen in this model (Pickard et al. 1993).

In postnatal rats, hypothyroidism diminishes, and $\mathrm{T} 4$ administration enhances, blood-brain glucose uptake (Moore et al. 1973). Maternal iodine deficiency is also associated with reduced blood-brain glucose uptake in weanling progeny, which can be prevented by feeding an iodine-replete diet from parturition (Sunitha et al. 1997). Although blood-brain glucose uptake largely reflects the activity of microvascular GLUT1, our results indicate that parenchymal GLUT1 is regulated in a similar manner during early fetal development. Indeed, thyroid hormone 
stimulates glucose transport in astrocytes in culture (Roeder et al. 1988).

Maternal hypothyroxinemia had no effect on GLUT1 mRNA levels in fetal brain and placenta, suggesting that changes in GLUT1 protein expression are mediated via translational or post-translational control mechanisms. Although thyroid status influences tissue GLUT1 mRNA in other in vivo models, close correspondence between GLUT1 protein and mRNA levels is not always apparent (Weinstein \& Haber 1992, Castelló et al. 1994). Thyroid hormone may modulate factors which bind to translational control elements in GLUT1 mRNA (Boado et al. 1996), the incorporation of GLUT1 protein into membranes or its degradation. Further work is required to explore these possibilities, however maternal hypothyroidism results in deficits in translational efficiency in fetal brain and placenta (Hendrich \& Porterfield 1996), and thyroid hormone has been shown to stimulate translation in neuronal cell cultures (Pickard et al. 1987).

Maternal hypothyroidism in the first half of rat gestation impairs the biosynthesis of metabolic stores which support fetal growth in late gestation (Bonet \& Herrera 1988). Furthermore, the administration of growth hormone, which does not cross the placenta, in late gestation to hypothyroid dams, can improve fetal metabolic deficits, though not consistently (Hendrich et al. 1997). These results suggest that maternal hypothyroidism induces maternal metabolic dysfunction. This factor is unlikely to impact in the present study since maternal hypothyroxinemia was induced well before, and not after, mating and was less severe. Indeed, body weights, tissue protein concentrations and serum glucose levels are depressed close to term in fetuses of hypothyroid dams (Morreale de Escobar et al. 1985, Bonet \& Herrera 1988, Porterfield \& Hendrich 1991, Hendrich et al. 1997) but were only transiently affected in the present study. It is difficult to envisage how fetal development could normalize if maternal metabolic compromise were responsible, since the latter is likely to worsen as pregnancy progresses and the feto-placental burden increases. Rather, the observation that catch-up occurs soon after the onset of fetal thyroid function favours a more direct influence for the maternal thyroid hormone supply on early fetal and placental development.

Placental weights are depressed in certain hypothyroid rat dam models (Bonet \& Herrera 1988, Hendrich \& Porterfield 1996) but normal in hypothyroxinemic dams (present study; Pickard et al. 1993). Deficits in the total protein concentration are seen however in placenta, but only at $19 \mathrm{dg}$ when the fetal thyroid is already functional and placental GLUT expression has normalized. The reasons for this are unclear, but gross placental dysfunction is unlikely since fetal body weights were normal at this age and remained so closer to term.

In conclusion, maternal hypothyroxinemia in the rat results in fetal growth retardation and impaired brain development before the onset of fetal thyroid hormone synthesis. Glucose uptake into brain parenchyma may be compromised both directly, due to deficient GLUT1 expression in this tissue, and indirectly, as a consequence of fetal hypoglycemia arising from reduced placental GLUT1 expression. Although reversed following the onset of fetal thyroid function, these effects occur during the critical period of blast cell proliferation and may therefore underlie the long term changes in brain development and function noted in this model (Pickard et al. 1993, 1997, Evans et al. 1999). Maternal hypothyroxinemia in human pregnancy is also associated with cognitive and motor dysfunction in offspring in the absence of change in fetal and placental weights at term (Man et al. 1991). Findings in the hypothyroxinemic rat dam model indicate that this brain dysfunction may arise from impaired brain development before active fetal thyroid hormone secretion, when both the fetus and the placenta are dependent upon the maternal circulation for their thyroid hormone supply.

\section{Acknowledgement}

This work was supported by a grant from Ortho-Clinical Diagnostics (Amersham, Bucks, UK).

\section{References}

Boado RJ, Tsukamoto H \& Pardridge WM 1996 Evidence for translational control elements within the $5^{\prime}$-untranslated region of GLUT1 glucose transporter mRNA. Journal of Neurochemistry 67 1335-1343.

Boileau P, Mrejen C, Girard J \& Hauguel-de Mouzon S 1995 Overexpression of GLUT3 placental glucose transporter in diabetic rats. Journal of Clinical Investigation 96 309-317.

Bondy CA, Lee W-H \& Zhou J 1992 Ontogeny and cellular distribution of brain glucose transporter gene expression. Molecular and Cellular Neurosciences 3 305-314.

Bonet B \& Herrera E 1988 Different response to maternal hypothyroidism during the first and second half of gestation in the rat. Endocrinology 122 450-455.

Bradford MM 1976 A rapid and sensitive method for the quantitation of microgram quantities of protein utilizing the principal of protein-dye binding. Analytical Biochemistry 72 248-254.

Burant CF, Sivitz WI, Fukumoto H, Kayano T, Nagamatsu S, Seino S, Pessin JE \& Bell GI 1991 Mammalian glucose transporters: structure and molecular regulation. Recent Progress in Hormone Research 47 349-388.

Castelló A, Rodríguez-Manzaneque JC, Camps M, Pérez-Castillo A, Testar X, Palacín M, Santos A \& Zorzano A 1994 Perinatal hypothyroidism impairs the normal transition of GLUT4 and GLUT1 glucose transporters from fetal to neonatal levels in heart and brown adipose tissue. Journal of Biological Chemistry 269 5905-5912.

Chomczynski P \& Sacchi N 1987 Single-step method of RNA isolation by acid guanidinium thiocyanate-phenol-chloroform extraction. Analytical Biochemistry 162 156-159.

Connolly KJ \& Pharoah POD 1989 Iodine deficiency, maternal thyroxine levels in pregnancy and developmental disorders in the children. In Iodine and the Brain, pp 317-331. Eds GR DeLong, J Robbins \& PG Condliffe. New York: Plenum Press. 
Dermietzel R, Krause D, Kremer M, Wang C \& Stevenson B 1992 Pattern of glucose transporter (Glut 1) expression in embryonic brains is related to maturation of blood-brain barrier tightness. Developmental Dynamics 193 152-163.

Evans IM, Sinha AK, Pickard MR, Edwards PR, Leonard AJ \& Ekins RP 1999 Maternal hypothyroxinemia disrupts neurotransmitter metabolic enzymes in developing brain. Journal of Endocrinology 161 273-279.

Ferreiro B, Bernal J, Goodyer CG \& Branchard CL 1988 Estimation of nuclear thyroid hormone receptor saturation in human fetal brain and lung during early gestation. Journal of Clinical Endocrinology and Metabolism 67 853-856.

Hendrich CE \& Porterfield SP 1996 Ribosomal protein synthesis in 16 and 19 day gestation fetuses of hypothyroid mothers. Proceedings of the Society for Experimental Biology and Medicine 213 273-280.

Hendrich CE, Ocasio-Torres W, Berdecia-Rodriguez J, Wiedmeier VT \& Porterfield SP 1997 Thyroid hormone regulation of brain amino acid utilization and protein synthesis in fetuses and progenies of hypothyroid mothers: a review. In Recent Research Developments in Neuroendocrinology - Thyroid Hormone and Brain Maturation, pp 87-102. Ed CE Hendrich. Trivandrum: Research Signpost.

Jones CT \& Rolph TP 1985 Metabolism during fetal life: a functional assessment of metabolic development. Physiological Reviews $\mathbf{6 5}$ 357-430.

Laemmli UK 1970 Cleavage of structural proteins during the assembly of the head of bacteriophage T4. Nature 227 680-685.

Man EB, Brown JF \& Serunian SA 1991 Maternal hypothyroxinemia: psychoneurological deficits of progeny. Annals of Clinical and Laboratory Science 21 227-239.

Moore TJ, Lione AP \& Regen DM 1973 Effect of thyroid hormone on cerebral glucose metabolism in the infant rat. American Journal of Physiology 225 925-929.

Morreale de Escobar G, Pastor R, Obregón MJ \& Escobar del Rey F 1985 Effects of maternal hypothyroidism on the weight and thyroid hormone content of rat embryonic tissues, before and after onset of fetal thyroid function. Endocrinology 117 1890-1900.

Morreale de Escobar G, Obregón MJ, Calvo R, Pedraza P \& Escobar del Rey F 1997 Iodine deficiency, the hidden scourge: the rat model of human neurological cretinism. In Recent Research Developments in Neuroendocrinology - Thyroid Hormone and Brain Maturation, pp 55-70. Ed CE Hendrich. Trivandrum: Research Signpost.

Mueckler M 1994 Facilitative glucose transporters. European Journal of Biochemistry 219 713-725.

Pickard MR, Sinha AK, Gullo D, Patel N, Hubank M \& Ekins RP 1987 The effect of 3,5,3'-triiodothyronine on leucine uptake and incorporation into protein in cultured neurons and subcellular fractions of rat central nervous system. Endocrinology 121 2018-2026.

Pickard MR, Sinha AK, Ogilvie L \& Ekins RP 1993 The influence of the maternal thyroid hormone environment during pregnancy on the ontogenesis of brain and placental ornithine decarboxylase activity in the rat. Journal of Endocrinology 139 205-212.

Pickard MR, Evans IM, Bandopadhyay R, Leonard AJ, Sinha AK \& Ekins RP 1997 Thyroid hormone action in rat brain from fetal to adult life. In Recent Research Developments in NeuroendocrinologyThyroid Hormone and Brain Maturation, pp 15-29. Ed CE Hendrich. Trivandrum: Research Signpost.

Porterfield SP \& Hendrich CE 1991 The thyroidectomized pregnant rat - an animal model to study fetal effects of maternal hypothyroidism. Advances in Experimental Medicine and Biology 299 107-132.

Roeder LM, Hopkins IB, Kaiser JR, Hanukoglu L \& Tildon JT 1988 Thyroid hormone action on glucose transporter activity in astrocytes. Biochemical and Biophysical Research Communications 156 275-281.

Ruiz de Ona C, Obregon MJ, Escobar del Rey F \& Morreale de Escobar G 1988 Developmental changes in rat brain 5'-deiodinase and thyroid hormones during the fetal period: the effects of fetal hypothyroidism and maternal thyroid hormones. Pediatric Research 24 588-594.

Shepherd PR, Gould GW, Colville CA, McCoid SC, Gibbs EM \& Kahn BB 1992 Distribution of GLUT3 glucose transporter protein in human tissues. Biochemical and Biophysical Research Communications 188 149-154.

Shin B-C, Fujikura K, Suzuki T, Tanaka S \& Takata K 1997 Glucose transporter GLUT3 in the rat placental barrier: a possible machinery for the transplacental transfer of glucose. Endocrinology 138 3997-4004.

Sinha AK, Prabakaran D, Godbole MM, Chattopadhyay N, Karmarkar M, Pickard MR, Leonard AJ \& Ekins RP 1997 Thyroid hormones and the human fetal brain. In Recent Research Developments in Neuroendocrinology - Thyroid Hormone and Brain Maturation, pp 1-14. Ed CE Hendrich. Trivandrum: Research Signpost.

Sunitha Y, Udaykumar P \& Raghunath M 1997 Changes in blood-brain barrier nutrient transport in the offspring of iodine-deficient rats and their preventability. Neurochemical Research 22 785-790.

Towbin H, Staehelin T \& Gordon J 1979 Electrophoretic transfer of proteins from polyacrylamide gels to nitrocellulose sheets: procedure and some applications. Proceedings of the National Academy of Sciences of the USA 76 4350-4354.

Trinder P 1969 Determination of glucose in blood using glucose oxidase with an alternative oxygen acceptor. Annals of Clinical Biochemistry 6 24-27.

Vannucci SJ 1994 Developmental expression of GLUT1 and GLUT3 glucose transporters in rat brain. Journal of Neurochemistry $\mathbf{6 2}$ 240-246.

Varghese S, Rydziel S, Jeffrey JJ \& Canalis E 1994 Regulation of interstitial collagenase expression and collagen degradation by retinoic acid in bone cells. Endocrinology 134 2438-2444.

Walker PS, Donovan JA, Van Ness BG, Fellows RE \& Pessin JE 1988 Glucose-dependent regulation of glucose transport activity, protein, and mRNA in primary cultures of rat brain glial cells. Journal of Biological Chemistry 263 15594-15601.

Wang C \& Brennan WA Jr 1988 Rat skeletal muscle, liver and brain have different fetal and adult forms of the glucose transporter. Biochimica et Biophysica Acta 946 11-18.

Weinstein SP \& Haber RS 1992 Differential regulation of glucose transporter isoforms by thyroid hormone in rat heart. Biochimica et Biophysica Acta 1136 302-308.

Zhou J \& Bondy CA 1993 Placental glucose transporter gene expression and metabolism in the rat. Journal of Clinical Investigation 91 845-852.

Received 19 February 1999

Revised manuscript received 10 May 1999

Accepted 13 July 1999 